\title{
Emotional training of online journalists via multimedia communicative projects linked to sustainable development
}

\author{
Ainara Larrondo Ureta, Jesús Ángel Pérez Dasilva, Koldobika Meso Ayerdi, Simón \\ Peña Fernández
}

Department of Journalism, University of the Basque Country, Spain.

\begin{abstract}
This paper describes an innovative pedagogic initiative for training Communication and Journalism university students. This initiative has been designed within the framework of a funded project financed. This has seeked to train future communicators in Transversal Competences (TC) via cooperative multimedia online journalism projects, focussed on subjects linked to the seventeen United Nations' Sustainable Development Goals, to be accomplished by all member States by the year 2030 (Agenda 2030). As this paper concludes, online journalist work with SDG projects can be a useful teaching strategy in the classroom for promoting learning skills and results sustained by the development of students' Emotional Intelligence (EI). In addition to contributing to the training of students in emotional competences, this innovative teaching initiative has led to develop other abilities related to EI, such as the capacity to work as part of a team.
\end{abstract}

Keywords: Online journalism; teaching; affective turn; SDG; report. 


\section{Introduction}

Different studies explain why online journalism has been one of the main driving forces in the renovation of study plans for Communication over the last decades (Tejedor, 2006; Larrondo \& Peña, 2018; etc.). By focussing on one specific case of teaching innovation, this paper seeks to justify the suitability of subjects about online journalism for innovating the university training of communicators via the so-called "affective turn" of the social sciences (Ticineto and Halley, 2007). As far as emotional training is concerned, from a basic and general viewpoint, this is a requisite that seems to be especially important in work environments such as that of online journalists. Here, strategies of newsroom convergence within the Communication Groups and the strategy of multi-channel content marks the need to work in multidisciplinary groups, with diverse work profiles, in a constantly changing environment where emotional tools are extremely useful - motivation, active listening, team vision, etc.

This work is supported by a double premise. On the one hand, the idea that emotions are a basic resource for working in online and converging newsrooms: the online journalist is a mediator with a service function and emotional qualities that are difficult to substitute by increasingly present journalistic robots. On the other hand, the idea that (online) journalism is a tool capable of generating emotions and raising awareness about the main socioeconomic problems that influence society, from the perspective of global initiatives such as Agenda 2030 and the Sustainable Development Goals (SDG).

\section{Emotions and journalism: educational challenges}

The interest in emotional discourses are dependent on current society in which the expression of emotions is made easier by the use of connected technological devices. These are considered "affective machines" and, in the specific case of social media, are even thought of as "affective technologies" with a capacity to reconfigure current conceptions about liberal democracies. There has also been talk of an "affective society" (Belli, Harré and Iñiguez, 2010).

Whilst it may be true that journalism should be supported by values such as objectivity and impartiality, in some cases the expression "emotional journalism" has been linked to an unethical kind of journalism, dictated by sentiment and prejudice, a kind of journalism that is partial or not very objective. Literature, cinema and television have been responsible for spreading clichés that have reinforced an image of the journalist who uses emotion negatively, and so it is not surprising that society holds contradictory opinions about these professionals. Be that as it may, in this work we refer to emotional journalism as an empathic, feeling journalism along the lines of the recent contributions from authors like Skare (2020). To mention just one example, in news concerning gender injustice an emotional journalism 
capable of moving the public has proved to be extremely useful. It is worth remembering also that the relationship with sources via social media has made these relationships more and more emotional, as highlighted in the research carried out by Sánchez \& Mendes (2013).

To speak of emotional educational competences in journalism therefore implies working in favour of the creation of an emotional awareness in students and future communicators. Some authors also speak of encouraging abilities linked to journalists' Emotional Intelligence (EI). As Paloma Sánchez explains (2012), EI contemplates various areas or components, among which are highlighted: a) the capacity for group organisation and effort coordination among people, personal connections, i.e. empathy for favouring contact with others; b) recognition and respect of feelings and interests, which, in short, leads to a command of the art of relationships; and c) the ability to detect and sense people's feelings, motives and interests, a knowledge that usually promotes the establishment and deepening of relationships with others (Sánchez, 2012).

EI conditions and influences the abilities, capacities and skills necessary for the correct practice of the journalist profession. Sánchez's work reflects on the significant role that emotional intelligence plays in the development of the interview genre on the part of the journalist. From a more global perspective, Óscar Herrero's book (2016) - La ventana interior. Inteligencia emocional aplicada al periodismo (The internal mirror. Emotional intelligence applied to journalism) - also examines the influence of emotional intelligence in the development of this professional activity.Thus emotional intelligence becomes a compliment to a purely theoretical and procedural or technical knowledge. For Herrero, journalists' emotional skills help them when it comes to elaborating and creating news. According to this same author, while integrity helps journalists to be rigorous with data, empathy helps them identify the concerns of others and deal with subjects that have real social relevance.

These emotional skills are directly related to journalistic ethics and creativity, given that emotional intelligence in journalists also implies the motivation and self-esteem to innovate (Dueñas, 2002). Such emotional skills can be perceived, therefore, in many of the Transversal Competences that many Faculties promote in their Communication study plans.

Emotional competences can have a more individual facet (personal skills) and another more social one (social skills). For online journalists, individual competences are important to function in the work environment in this professional field (confidence and an adequate assessment of oneself, understanding and recognition of one's own feelings, etc.), whilst those of a more social nature would have a bigger impact on their function and role of service to society, i.e. those which derive from an attitude of empathy towards others (a capacity to anticipate society's needs, a capacity to understand the interests and needs of the public, the need to give a voice to the voiceless etc.). 
Applying the model of components that Goleman (1999) considers make up EI in the field of journalism, it could be concluded that journalists that have a greater emotional intelligence are also more capable of communicating better, of being team leaders and working cooperatively, of influencing others and solving conflicts. Goleman's model is interesting because it applies emotional development not only to the personal, but also to the organisational field. In this sense, the following statement by Goleman could also be applied to the field of communication and journalism in a context in which the media companies tend to converge into multimedia teams and in which there is more and more talk of the need to recuperate journalistic values, such as the search for truth and an in-depth, reflexive journalism which is above and beyond the consumption of fast journalism: "With their emphasis on flexibility, teams and a strong leaning towards service, emotional competences will be more and more decisive in obtaining excellence"(Goleman, 1999: 52). As Sánchez states (2012: 124), "the development of emotional intelligence competences in the journalism profession is necessary because all communicative processes are influenced by intrapersonal intelligence".

\section{Analysis}

\subsection{Context: pedagogical innovation in (online) journalism via SDGs}

Within this context of constant technological, communicative and pedagogic adaptation, the University of the Basque Country introduced during the 2011/2012 academic year, the subject "Online News Writing", an obligatory subject in the second year of Degrees in Audiovisual Communication, Journalism and Advertising and Public Relations. Since its introduction, this subject has sought to strengthen those skills necessary for creating messages adapted to the characteristics and possibilities of online news media, in real time, and for working collaboratively to develop online journalistic projects with a multi-platform and social perspective. Thus, this subject develops a didactic approach related with content and genre (news, report, infographics, feature, interview...), narrative styles (multimedia, transmedia...) and formats (text, video, audio, image, etc.). From a general theoretical point of view, the subject aims to offer the necessary resources for "learning to learn" about web culture and familiarise the student with the increasingly more complex media ecosystem of the Internet. In fact, online journalism professionals are renowned for their creative capacity and their innovation.

The subject of Online News Writing (UPV/EHU) has become a hotbed of pedagogic innovation in the last decade and has been the object of four Educational Innovation Projects (PIE), all developed by the KZ-Berri Gureiker Group (IT1112-16), of the University of the Basque Country (UPV/EHU). This paper gives an account of the latest of these projects, entitled "Teaching to communicate in and for a globalised world. Promotion of Transversal 
Competences (TC) and Sustainable Development Goals (SDG) in learning based on enterprising transmedia projects".

\subsection{Methodology}

The aim of the project is to propose value-added methodological formulae to update the university teaching of the Specific Competences (SC) of the subject, linked to multimedia online journalistic formats and genres via the development of Transversal Competences (TC) for the development of a more responsible, sensitized and critical vision of online journalists in relation to current social problems connected to a global and digitalised public. More specifically, the project has sought to implement six of the TCs indicated by the UPV/EHU (2019): Innovation and Enterprise; Social Commitment; Ethics and Professional Responsibility; News Management and a Digital Public; Critical Thought; and Teamwork.

As a result, this subject began, in the 2020/2021 academic year, to take advantage of different teaching methodologies to transmit the theoretical-practical content linked to the practice of journalism in the new environment, and to train online journalists in values and emotions. These methodologies included Project Based Learning (PBL), useful for simulating real professional environments. It is not surprising that previous studies have made clear the need to already begin practising teamwork at university with real projects (television programmes, specific radio, reports...) that help students "to begin learning to work in this profession, so as not to find themselves, as currently happens, without experience in team management when they start their first job (Sánchez, 2012: 211).

Over the first four months of the 2020/2021 year, teaching staff who cover the subject in the different groups (Spanish, Basque and English) have used PBL for the cooperative creation of multimedia reports about subjects linked to SDGs. This kind of in-depth project entailed individual and cooperative work strategies. The development of this type of project has sought to instil in students professional values such as responsibility, teamwork, selfsufficiency and empathy with readers in the online environment, with the aim of teaching how to apply new creative approaches to the solving of current problems in the field of communication. Among these problems it is worth highlighting mainly the tendency towards rapid, instant news (fast journalism), lacking in depth and, in many cases with sensationalist and commercial traits, as is shown by the expansion of phenomena such as clickbait. This is centred on the diffusion of headlines that do not seek to inform but to capture the reader's attention like a fish to a hook, by generating an emotional reaction that leads him or her to click on that information.

We are currently in times of many changes that involve intense transformations. It is true that, perhaps, journalism has partly forgotten its role of power guard dog, but this has coincided with a relaxation that can be felt in the whole of society. Entertainment has eaten away at information and, 
when this finds a space, it is nearly always of rapid consumption. Evasion takes precedence over reflection. In this context, it is not easy to provide quality news that has been worked in depth. Even so, we must continue with a commitment to providing content that isn't consumed in 30 seconds and that is more than a mere number of "clicks" (Herrero, 2017)

The UNESCO (2019) approach to Sustainable Development Goals and the media places emphasis on the thematic agenda and the treatment of the news, but also on other directly related issues, such as journalistic education. In this regard, the UNESCO refers to the importance of generating "inclusive approaches aimed at strengthening journalism throughout the world". The UNESCO recognises the importance of promoting didactic methodologies for university education, the aim of which is to develop future communicators with a conscience and an appreciation of the treatment of subjects related to SDGs, such as that of the aforementioned UPV/EHU project.

In order to carry out pedagogic innovation in the subject of Online News Writing, groups of four students worked individually, collaboratively and cooperatively both inside and outside the classroom to conceive, plan and produce news reports or websites whose aim was the indepth treatment of subjects linked to SDGs. Each work sub-group undertook the following tasks, organised in phases:

1. Preparation phase/Hackathon (collective innovation). The sub-groups work to think together and identify opportunities for innovation and the launching of public interest reports with different approaches (thematic hyperspecialisation in SDG, microtargetting, etc.).

2. Analysis and exploration phase. Each sub-group must assess the interest of the report in relation to the market and the current media business, viability, etc.

3. Product development phase (report, docuweb, special web, etc.). Each in-depth news product (website or special report) will be extended towards other media or communicative fields (transmedia approach) via public presentations, classroom debates, podcasts, etc. The initiative also considered the promotion of these experiences via social media, together with management and application for the development of different tools for the creation of news timelines, infographics and interactive images, among others. Two illustrative examples of the developed products are shown below.

\subsection{Results and final reflections}

During the 2020/2021 academic year, over fifty cooperative multimedia reports were produced, either directly or transversally linked to SDGs. To assess the degree of interest in the proposed methodology of pedagogic innovation, in the last few weeks of the Online News 
Writing subject (December 2020 - January 2021) a questionnaire consisting of fifteen open and closed questions was given to all the students participating in the multimedia reports. Opinions were also gathered from the teaching staff involved in the initiative. The 158 questionnaires completed in the project reflected the need for working on aspects linked to the coordination of work groups on all levels, such as emotional training for future (online) journalists, approaching and addressing the subject agenda or coverage from a social commitment perspective. The results of the questionnaires show there is a great interest in working with SDGs in the classroom in order to achieve greater student involvement in their own training process, and in the generation of a specific identity as online journalists committed to their service role in a complex, internationalised or global society.

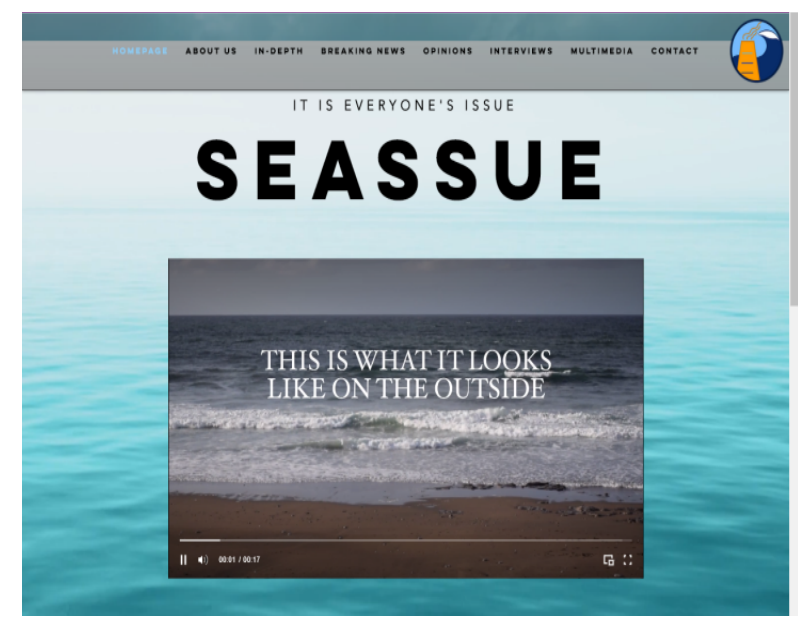

Figure 1. An example of the multimedia report created by the students.

(SDG fourteen: Conserve and sustainably use the oceans, seas and marine resources for sustainable development) Source: https://seassue.wixsite.com/seassue

In view of the results obtained from the questionnaires and the majority percentages, it is possible to summarise some main ideas. On the one hand, the aims of the use of report is appropriate for working with SDGs, and the work and experience in the classroom has served to increase the students' level of empathy and awareness. This advance is especially notable in the case of problems linked to gender inequality and poverty (fifth SDG). At the same time, they have recognised that working with the SDGs has allowed them to promote the transversal competences highlighted in our teaching innovation proposal: Innovation, Social Commitment, Ethics and Professional Responsibility, News Management and a Digital Public, Critical Thought and Teamwork. Innovation was necessary to try to find different, original approaches regarding these subjects when they had already been dealt with by other news media. Likewise, news management was necessary when it came to prioritising the news provided by digital source documents and personal sources. 
The students maintain that they are now more conscious of the importance of certain subjects and treatments for transmitting to a global audience powerful, quality news capable of fostering action and achieving the development aims established by the UNESCO. What's more, some of the comments make it clear that these subjects have had a great "impact" on these students. Similarly, the surveyed students recognise having increased their level of perception or awareness about the kind of treatment given by the media to these aims and their subject matter, which is still limited according to general opinion. What can be seen from the opinions given is the relevance of this methodology for making students reflect and move away from an excessive dependency on, or collusion with official sources in favour of another type of source and groups of interest (NGOs, neighbourhood associations, social movements, etc.).

Ultimately, at a time when there is a call for a more responsible journalism (committed to gender equality, sustainability, etc.) against an instantaneous, fragmented and sometimes superficial or sensationalist news, this paper shows that the consideration of SDGs within a context of journalistic education is effective. Online journalism needs trained professionals to respond to the constraints of current audiences. To this end, competences such as the ability to "move" and engage via subjects, which are of interest to the public are relevant, such as those linked to the seventeen SDGs. This initiative thus reveals the interest in and need to recuperate the social function of (online) journalism by applying the tendency of "affective turn" in Social Sciences and in higher education.

\section{References}

Belli, S., Harré, R., \& Íñiguez, L, (2010). Emociones y discurso: Una mirada a la narrativa científica de la construcción social del amor. Prisma Social, 4, 1-45.

Dueñas Buey, M. L. (2002). Importancia de la inteligencia emocional: un nuevo reto para la orientación educativa. Educación XX1, 5, 77- 96. DOI: 10.5944/educxx1.5.1.384.

Goleman, D. (1999). La práctica de la Inteligencia Emocional. Barcelona: Paidós.

Herrero, Ó. (2017). Inteligencia emocional, indispensable para afrontar los cambios que vive el periodismo. Ética Segura: http://eticasegura.fnpi.org/2016/09/26/inteligenciaemocional-periodismo-oscar-herrero-conde-ventana-interior-entrevista/ DOI: 10.5209/rev_CIYC.2013.v18.41720

Larrondo, A., \& Peña, S. (2018). Keeping pace with journalism training in the age of social media and convergence: How worthwhile is it to teach online skills? Journalism, 19(6), 877-891. DOI: 10.1177/1464884917743174

Sánchez, P. (2012). La inteligencia emocional en el entrevistador periodístico: competencias $y$ formación. Tesis Doctoral. Universidad Católica de San Antonio (Murcia). https://www.educacion.gob.es/teseo 
Sánchez, H. M., \& Méndez, S. (2013). "Nuevos medios, nuevos perfiles y conectividad emocional con la audiencia: los periodistas en la praxis profesional". CIC. Cuadernos de Información y Comunicación, 18,133-149.

Skare, K. (2020). "Discussing Emotions in Digital Journalism". Digital Journalism, 8(2), 292-297. DOI: 10.1080/21670811.2020.1727347

Tejedor, S. (2006). La enseñanza del ciberperiodismo. Tesis doctoral. Barcelona: Universidad Autónoma de Barcelona.

Ticineto, P. y Halley, J. (Eds.) (2007). The affective turn: theorizing the social. Durham: Duke University Press. 